\title{
PENGARUH PERSEPSI MAHASISWA AKUNTANSI TENTANG PAJAK DAN BREVET PAJAK TERHADAP MINAT BERPROFESI DIBIDANG PERPAJAKAN
}

\author{
Asep Suherman \\ Universitas Pamulang \\ dosen02438@unpam.ac.id
}

\begin{abstract}
This research was counducted at the University of Pamulang the purpose of this study was to determine the effect of Accounting Students' Perceptions of Taxes and Taxes on Profession Interest in Taxation. The results of this study indicate that Perceptions about Tax have a partially positive effect on Interest in Profession in the Taxation Sector. F there is a significant influence between $X 1$ and X2 simultaneously on the interests of working in the taxation field. Perception of Tax and Brevet tax in the Adjusted R Square Test of 0.114 means that the variable of interest in the taxation profession can be explained by the perception variable about tax and tax brevet of $11.4 \%$ or it can be said that the variable perception of tax and tax brevet can influence interest in the profession taxation of $11.4 \%$.
\end{abstract}

Keywords: Perception about tax, tax brevet, interest

\section{PENDAHULUAN}

Bagi negara pajak dilihat penting sebab pajak adalah salah satu pendapatan, yang berfungsi untuk pembangunan disuatu negara. Institusi swasta memiliki kewajiban untuk membayar pajak dan harus dihandel dengan baik, maka diperlukan orang-orang yang profesional untuk mengerjakan pajak disuatu negara. Defiandry Taslim (2007) mengemukakan alasan pentingnya profesi di bidang perpajakan sebagai berikut:

"Pajak sebagai tulang punggung penerimaan negara, tentu tidak dapat dikelola dengan baik dan transparan tanpa tersedianya sumber daya manusia yang mempunyai kecakapan,kompetensi, dan integritas yang tinggi mengingat tugas utama dan mulia dari perpajakan sebagai lini terdepan dalam proses 
pendanaan pembangunan dinegara kita. Untuk itu, peranan beberapa profesi penunjang perpajakan harus dikembangkan secara profesional,diakui oleh semua pihak dan telah memenuhi kualifikasi yang dibutuhkan dalam rangka berjalannya mekanisme perpajakan dengan baik dan accountable."

Pekerjaan konsultan terbilang menjanjikan bagi mahasiswa ataupun sarjana akuntansi, sebab pekerjaan konsultan pajak diperlukan untuk badan atau institusi pemerintahan ataupun swasta. Sedangkan ketertarikan para alumni untuk berkerja sebagai konsultan di perpajakan rupanya masih benar-benar kurang. Bedasarkan ketua (IKPI) Cabang Semarang JM Harianto dalam Harry Susilo (2008) menyatakan

"Jumlah konsultan pajak yang terdaftar ada 40 orang, sedangkan potensi wajib pajak ada sekitar 5.000-an, pangsa pasar masih terbuka lebar untuk profesi ini."

Pernyataan tersebut dilontarkan pada uji sertifikasi konsultan pajak brevet di semarang pada tanggal 25 November 2008. pekerjaan konsultan pajak dibutuhkan di dunia bisnis semenjak dikeluarkanya "PMK No 22/PMK.03/2008" pada tanggal 6 februari 2008 prihal salah satu persyaratan, pelaksanaan, hak dan kewajiban seorang kuasa yang lebih memberikan ruang terhadap konsultan pajak yang teregistrasi di dalam memberikan jasa konsultan pajak. JM Harianto dalam Harry Susilo (2008) menyebutkan bahwa salah satu kurangnya ketertarikan menjadi konsultan pajak yaitu alasan ekonomi dan minat.

Brevet pajak merupakan salah satu program yang tujuanya bermaksud memberikan kepada mahasiswa sebagai pengetahuan, keterampilan pajak. Sertifikat yang didapat untuk yaitu orang yang menguasai pajak orang pribadi (sertifikat A), orang yang menguasai pajak badan (sertifikat B) dan orang yang menguasai perpajakan internasional (sertifikat C). Para sarjana akuntansi jika berkeinginan berkerja sebagai konsultan harus mempunyai sertifikat tersebut dan mengikuti USKP. 
Pengetahuan seputar brevet pajak kemungkinan masih sangat kurang bagi sebagian mahasiswa jurusan akuntansi. Hal ini dikarenakan masih sebagian mahasiswa yang mengikuti Brevet Pajak, (Alfie Rizky 2013).

Berdasarkan latar belakang tersebut makan penulis berminat untuk melaksanakan penelitian mengenai "Pengaruh Persepsi Mahasiswa

\section{Akuntansi Tentang Pajak Dan Brevet Pajak Terhadap Minat Berprofesi Di Bidang Perpajakan"}

\section{TELAAH LITERATUR DAN PENGEMBANGAN HIPOTESIS}

\section{Pengertian pajak}

Pajak merupakan pungutan rakyat terhadap negara yang menurut peraturan pemerintah, tidak memperoleh imbalan yang bisa langsung digunakan manfaatnya secara umum bedasarkan Prof.Dr. Rachmat Soemitro, S.H.. Definisi berbeda dari pajak sendiri ialah peralihan kekayaan dari rakyat terhadap kas negara untuk membiayai pengeluaran rutin dan surplusnya diterapkan sebagai publik saving yaitu sumber utama untuk pembiayaan publik investment. dari pengertian pajak tersebut maka dapat diambil kesimpulan bahwa pajak mempunyai beberapa ciri utama yaitu pajak dipungut dan diatur oleh undang-undang sebagai pedoman pelaksanaanya, pemerintah mengunakan pajak untuk pembiayaan pengeluaran kegiatannya dan publik investment apabila ada surplus.

\section{Fungsi pajak}

Pajak berfungsi sebagai anggaran yaitu sebagai salah satu pemasukan negara untuk pembanguan dan untuk membiayai pengeluaran lainya, dengan adanya pemungutan pajak dapat meningkatkan pemasukan negara, dan pajak berfungsi pengatur yaitu sebagai salah satu untuk mengambil keputusan pemerintah, misalnya pengusaha bisa dikenakan pajak dari hasil produksi sesuai peraturan yang berlaku, jadi perusahaan yang mempunyai penghasilan yang tinggi dapat berkontribusi. 


\section{Pengertian profesi/ pekerjaan}

Seseorang yang mempunyai pekerjaan/profesi disebut profesianal, karena pekerjaan membutuhkan pengetahuan dan keterampilan. Berikut pekerjaan berdasarkan Victor S. G. Tengker dan Jenny Morasa (2007) :

- Mempunyai ilmu, yaitu merupakan petunjuk untuk mengerjakan keprofesiannya.

- Mempunyai etika sebagai petunjuk untuk mengontrol perilaku temanya dalam pekerjaan itu.

- Mempunyai organisasi yang legal dan diakui oleh pemerintah dan masyarakat sekitar..

- Mempunyai ilmu yang diperlukan orang banyak.

- Bekerja dilandasi sebagai bentuk kepercayaan orang banyak.

\section{Profesi di Bidang Perpajakan}

Victor S. G. Tengker dan Jenny Morasa (2007) dalam "International Federation of Accountants":

"Profesi akuntan adalah semua bidang pekerjaan yang mempergunakan keahlian di bidang akuntansi, termasuk bidang pekerjaan akuntan public, akuntan intern yang bekerja pada perusahaan industri, keuangan atau dagang, akuntan yang berkerja pada pemerintah atau akuntan sebagai pendidik. Dalam arti sempit, profesi akuntan adalah lingkup pekerjaan yang dilakukan oleh akuntan sebagai akuntan public yang lazimnya terdiri dari pekerjaan audit, akuntansi, pajak dan konsultan manajemen."

Erlysuandy,2001) menyebutkan bahwa, konsultan pajak seharusnya mempunyai kualifikasi pendidikan dan mempunyai izin memberikan bimbingan atau nasihat perpajakan dengan motif fee atau imbalan. Seorang konsultan pajak dituntut mengeluarkan usul-usul atau masukan mengenai prinsip dan manajemen perpajakan yang wajib dicapai oleh kliennya sesuai perartuaran yang berlaku. 


\section{Minat berprofesi dibidang perpajakan}

Minat ialah keinginan seseorang yang didasarkan oleh perasaan keinginan yang mendalam misalnya rasa senang terhadap sesuatu, berdasarkan Tidjan dalam Haryanto (2010) sedangkan M.Dimyati Mahmud dalam Haryanto (2010) memberikan definisi minat yakni "kekuatan pendorong yang memaksa seseorang menaruh perhatian pada orang situasi atau aktivitas tertentu dan bukan pada yang lain, atau minat sebagai akibat yaitu pengalaman efektif yang distimular oleh hadirnya seseorang atau sesuatu objek, atau karena berpartisipasi dalam suatu aktivitas" dari definisi tersebut dapat disimpulkan bahwa minta adalah salah satu keinginan yang diinginkan seseorang untuk mencapai tujuan diprofesinya, maka ini dikaitkan dengan minat dibidang perpajakan.

\section{Pengertian Persepsi}

Persepsi sebagai sebagai salah satu proses mengorganisir, dan mengitingkat ekonomi yang dirasakan bangsa Indonesia mulai mengalami peningkatannteprestasikan kepada ilustrasi dunia, menurut Siegel dan Marconi dalam Rochman Effendi (2000). Robbins dalam Rochman Effendi (2000) persepsi merupakan proses mengorganisasikan,menginteprestasikan untuk memberikan kesan terhadap dunia. Lebih lanjut, Cherington dalam Rochman Effendi (2000) mengarikan persepsi sebgai proses penafsiran dan penerimaan rangsangan yang berasal dari lingkungan.

M. Dimyati Mahmud (1990) mengartikan persepsi sebagai sebuah tafsiran dari stimulus yang ada didalam otak. Dalam melukiskan gejala persepsi ini, menurut Laura A.King (2010), "persepsi (perception)merupakan proses mengatur dan mengartikan informasi sensoris untuk memberikan makna". DavidMarr dalam LauraA.King (2010) menyatakan tujuan persepsi merupakan perwakilan internal dari dunia luar.

Salah satu unsur yang benar-benar memberikan pengaruh persepsi ialah perhatian. Kenneth E.Andersen dalam Jalaluddin Rakhmat (2007) memberikan penjelasan mengenai perhatian sebagai berikut : 
"Perhatian adalah proses mental ketika stimuli atau rangkaian stimuli menjadi menonjol dalam kesadaran pada saat stimuli lainnya melemah. Perhatian terjadi apabila kita mengkonsentrasikan diri pada salah satu alat indera kita, dan mengesampingkan masukan-masukan melalui alat indera yang lain"

Kohler, Wartheimer, dan Koffka dalam Jalaluddin Rakhmat (2007) menyatakan "jika kita ingin memahami suatu peristiwa, kita tidak dapat meneliti fakta-fakta yang terpisah, kita harus memandangnya dalam hubungan keseluruhan".

Dari beberapa pengertian mengenai persepsi tersebut, dapat ditarik kesimpulan bahwa persepsi ialah proses yang meliputi penerimaan, pengorganisasian, dan penafsiran dengan cara memberi pengaruh sikap seseorang atau perilaku.

\section{METODOLOGI PENELITIAN}

\section{Jenis penelitian}

Penelitian ini menggunakan penelitian kuantitatif yang menggunakan data angka yang diolah secara sistematis dengan mengunakan rumus statistik (Marzuki,2005) penelitian yang diolah dari hasil jawaban / tanggapan dari pertanyaan yang diberikan kepada masyarakat .

\section{Metode pengumpulan data}

Metode yang digunakan dalam pengambilan sample adalah convenience sampling yaitu pengambilan sampling sebagai pertimbangan kemudahan saja. Kriteria responden adalah:

1. Masih aktif sebagai mahasiswa program studi akuntansi S1 di Universitas Pamulang Tangerang.

2. Perpajakan $1 \& 2$ dan Pajak Internasional

3. Telah atau sudah mengikuti Brevet Pajak

"Jumlah sampel dalam penelitian ini menggunakan teori jika ukuran sampel lebih dari 30 dan kurang dari 500 adalah tepat" menurut 
(Rescoe,1982:253) Sehingga penelitian menentukan jumlah sampel sesuai kriteria responden sebanyak 60 Sampel.

\section{Metode analisis data}

Jenis data yang peneliti gunakan adalah kualitatif berupa hasil jawaban kuesioner yang telah diberikan sebelumnya ke mahasiswa fakultas ekonomi akuntansi S1 universitas pamulang.

\section{Operasional Variabel Penelitian}

Penelitian ini ada dua variabel minat berprofesi dibidang perpajakan adalah variabel terikat (dependent variable), untuk persepsi pajak dan persepsi brevet pajak adalah variabel bebas (independent variabel).

\section{HASIL PENELITIAN DAN PEMBAHASAN}

Karakteristik Responden

Penelitian ini menggunakan data yang dikumpulkan adalah dengan penelitian dilapangan, untuk memperoleh info dengan memberikan kuesioner. Jumlah responden yang dapat menjadi subjek penelitian ini yaitu mahasiswa Ekonomi Akuntansi yang mengambil Konsentrasi Perpajakan yang sedang menempuh semester 7 dan semester 8 . dalam table berikut :

\begin{tabular}{|l|c|c|c|c|}
\hline Keterangan & $\begin{array}{c}\text { Mahasiswa } \\
\text { Reguler A } \\
(\mathrm{N}=20)\end{array}$ & $\begin{array}{c}\text { Mahasiswa } \\
\text { Reguler B } \\
(\mathrm{N}=20)\end{array}$ & $\begin{array}{c}\text { Mahasiswa } \\
\text { Reguler C } \\
(\mathrm{N}=20)\end{array}$ & $\begin{array}{c}\text { Jumlah } \\
(\mathrm{N}=60)\end{array}$ \\
\hline $\begin{array}{c}8(40 \%) \\
\text { laki-laki }\end{array}$ & $\begin{array}{c}5(25 \%) \\
15(75 \%)\end{array}$ & $\begin{array}{c}13(65 \%) \\
7(35 \%)\end{array}$ & $\begin{array}{c}26(43 \%) \\
34(57 \%)\end{array}$ \\
\hline $\begin{array}{c}\text { usia } \\
\text { perempuan }\end{array}$ & $20(100 \%)$ & $16(80 \%)$ & $6(30 \%)$ & $42(70 \%)$ \\
25-30 Tahun & - & $4(20 \%)$ & $10(50 \%)$ & $14(16 \%)$ \\
$>30$ Tahun & - & - & $4(20 \%)$ & $4(14 \%)$ \\
\hline pendidikan & $14(70 \%)$ & $20(100 \%)$ & $20(100 \%)$ & $44(73 \%)$ \\
SMA / SMK & $6(30 \%)$ & - & - & $6(27 \%)$ \\
D3 & - & & & \\
S1 & & &
\end{tabular}




\section{Uji asumsi klasik}

1) Normalitas data

Berikut merupakan data hasil output SPSS uji normalitas dengan uji kolmogorov smirnov dan normal probability plot sebagai berikut :

\begin{tabular}{|c|c|c|}
\hline \multicolumn{3}{|c|}{ One-Sample Kolmogorov-Smirnov Test } \\
\hline & & $\begin{array}{l}\text { unstandardized } \\
\text { residual }\end{array}$ \\
\hline 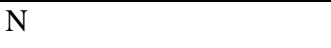 & & 60 \\
\hline normal parameters ${ }^{\mathrm{a}, \mathrm{b}}$ & mean & ,0000000 \\
\hline & std. deviation & 9,60603746 \\
\hline most extreme differences & absolute & ,108 \\
\hline & $\begin{array}{l}\text { positive } \\
\text { negative }\end{array}$ & $\begin{array}{r}, 076 \\
-, 108\end{array}$ \\
\hline test statistic & &, 108 \\
\hline asymp. sig. (2-tailed) & &, $077^{\mathrm{c}}$ \\
\hline
\end{tabular}

a. Test distribution is Normal.

b. Calculated from data.

c. Lilliefors Significance Correction.

Berdasarkan uji normalitas menunjukan nilai 0,77>0,05 jadi normalitas layak digunakan.

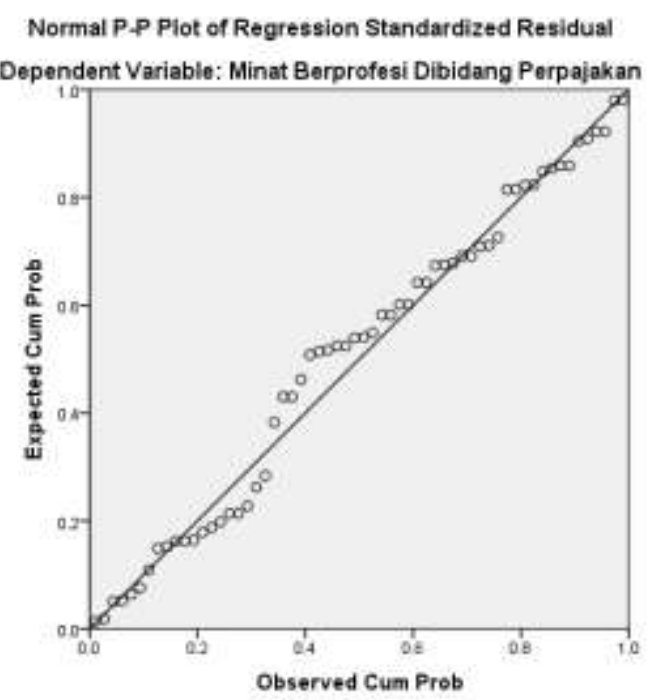

Hasil uji mengambarkan titik-titik menyebar diarea garis diagonal, hasil uji ini menyatakan layak digunakan walaupun masih sedikit titik yang keluar garis diagonal. 


\section{Uji Multikolonieritas}

\begin{tabular}{|c|c|c|c|c|c|c|c|c|}
\hline \multicolumn{9}{|c|}{ Coefficients $^{\mathrm{a}}$} \\
\hline \multirow{2}{*}{\multicolumn{2}{|c|}{ Model }} & \multicolumn{2}{|c|}{$\begin{array}{c}\text { Unstandardized } \\
\text { Coefficients }\end{array}$} & \multirow{2}{*}{$\begin{array}{c}\begin{array}{c}\text { Standardiz } \\
\text { ed } \\
\text { Coefficient } \\
\text { s }\end{array} \\
\text { Beta } \\
\end{array}$} & \multirow[b]{2}{*}{$\mathrm{t}$} & \multirow[b]{2}{*}{ Sig. } & \multicolumn{2}{|c|}{$\begin{array}{l}\text { Collinearity } \\
\text { Statistics }\end{array}$} \\
\hline & & $\mathrm{B}$ & Std. Error & & & & $\begin{array}{c}\text { Toleran } \\
\text { ce }\end{array}$ & VIF \\
\hline & (Constant) & 21.077 & 11.975 & & $\overline{1.760}$ & .084 & & \\
\hline & $\begin{array}{l}\text { Persepsi Tentang } \\
\text { Pajak }\end{array}$ & .628 & .274 & .315 & 2.293 & .026 & .798 & 1.254 \\
\hline & $\begin{array}{l}\text { Persepsi Tentang } \\
\text { Brevet Pajak }\end{array}$ & .325 & .390 & .114 & .834 & .408 & .798 & 1.254 \\
\hline
\end{tabular}

a. Dependent Variable: Minat Berprofesi Dibidang Perpajakan

Berdasarkan hasil uji multikolonieritas tidak terjadi multikolinearitas karena nilai VIF nilainya lebih kecil dari 10,00 jika dilihat dari masing-masing variabel.

\section{Uji Heterokedastisitas}

Pengujian menggunakan SPSS versi 22.00 hasilnya adalah sebagai berikut :

$$
\text { Scatterplot }
$$

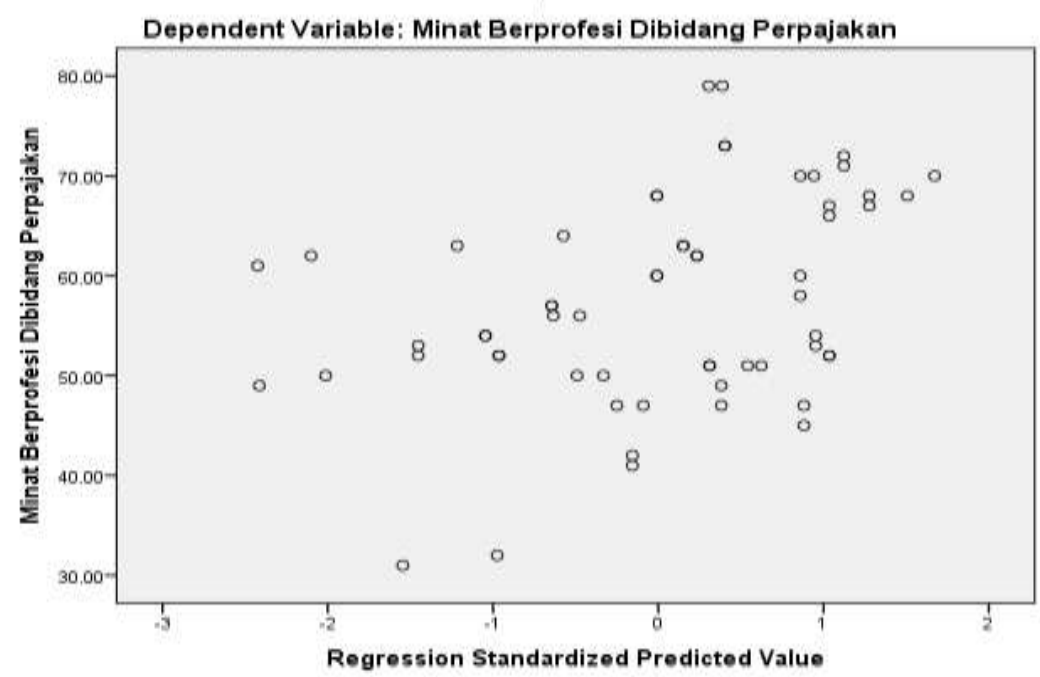

Dari hasil heteroskedastisitas tidak ada masalah heteroskedastisitas karena titik tersebut tidak membentuk pola. 
Analisis regresi berganda

\begin{tabular}{|c|c|c|c|c|c|}
\hline \multirow[b]{2}{*}{ model } & \multicolumn{2}{|c|}{ unstandardized coefficients } & \multirow{2}{*}{$\begin{array}{c}\text { standardized } \\
\text { doefficients }\end{array}$} & \multirow[b]{2}{*}{$\mathrm{t}$} & \multirow[b]{2}{*}{ sig. } \\
\hline & B & Std. Error & & & \\
\hline (constant) & 21.077 & 11.975 & & 1.760 & .084 \\
\hline persepsi tentang pajak & .628 & .274 & .315 & 2.293 & .026 \\
\hline $\begin{array}{l}\text { persepsi pentang brevet } \\
\text { pajak }\end{array}$ & .325 & .390 & .114 & .834 & .408 \\
\hline
\end{tabular}

a. Dependent Variable: Minat Berprofesi Dibidang Perpajakan

Melalui persamaan diatas, dapat diinteprestasikan bahwa apabila X1 dan X2 berada pada sekor minimum, maka minat berprofesi dibidang perpajakan (Y) nilainya 21,077. koefisien regresi variabel persepsi tentang pajak (X1) senilainya 0,628 memberikan pengertian bahwa apabila variabel bebas mempunyai nilai yang tidak berubah dan persepsi tentang pajak akan naik sebesar 1 (satu), maka minat berprofesi dibidang perpajakan (Y) akan naik 0,628. koefisien mempunyai nilai yang positif, artinya persepsi tentang pajak dengan minat berprofesi di bidang perpajakan mempunyai hubunhan yang positif. Koefisien regresi variabel X2 senilai 0,325 menunjukan bahwa jika variabel bebas lainya bernilai tetap dan persepsi tentang brevet pajak mengalami peningkatan sebesar 1 satuan maka minat berprofesi dibidang perpajakan akan mengalami kenaikan 0,325.

koefisien determinasi $\left(\mathrm{R}^{2}\right)$

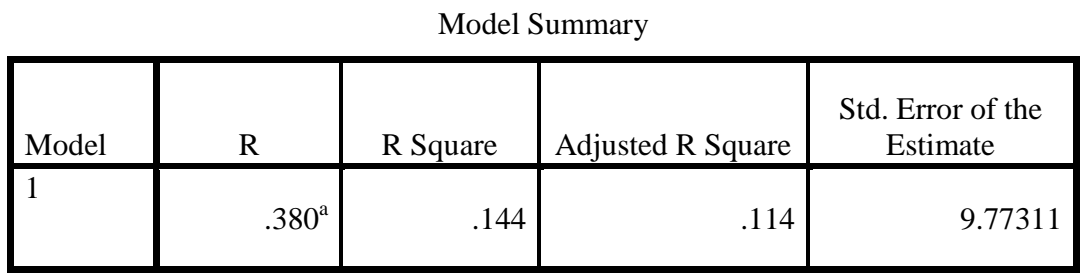

a. Predictors: (Constant), Persepsi_Tentang_Brevet_X2,

Persepsi_Tentang_Pajak_X1 
Dari analisis mengenai $\mathrm{R}^{2}$ adalah Adjusted R Square 0,114 yang artinya persepsi tentang pajak dan brevet pajak mempunyai pengaruh terhadap minat berprofesi dibidang perpajakan yaitu 11,4\% dan 88,6\% dipengaruhi oleh variabel yang tidak diteliti.

uji F ( Pengujian Secara Silmultan)

Uji statistic secara silmultan untuk variabel bebas $\mathrm{X}_{1}$ dan variabel bebas $\mathrm{X}_{2}$ diperoleh hasil sebagai berikut:

F hitung bernilai 4.809 nilai kesadaran 5\% dimana df;a, (k-1),(n-k)atau(3-1), (60-3) diperoleh besarnya $\mathrm{F}$ table sebesar 3,16 sehingga $\mathrm{F}$ hitung $>\mathrm{F}$ table maka variabel X1 dan Variabel X2 terdapat pengaruh yang signifikan, secara simultan terhadap minat berprofesi dibidang perpajakan.

\section{SIMPULAN}

1. Hasil penelitian menunjukan nilai uji t sebesar 2,995 berarti hitungan. $t$ table $(2.995>1,670)$ memiliki nilai $0,004<0,05$. jika persepsi seorang mahasiswa tentang pajak baik, maka minatnya pun akan baik di bidang perpajakan.

2. Hasil penelitian menunjukan nilai uji F 4.809 maka variabel X1 dan Variabel X2 terdapat pengaruh yang signifikan, secara simultan terhadap minat berprofesi dibidang perpajakan.

3. Adjusted R Square 0,114 yang artinya persepsi tentang pajak dan brevet pajak mempunyai pengaruh terhadap minat berprofesi dibidang perpajakan yaitu $11,4 \%$ dan $88,6 \%$ dipengaruhi oleh variabel yang tidak diteliti.

\section{REFERENSI}

Bhuono Agung Nugroho. 2005. "Strategi Jitu Memilih Metode Statistik Penelitian Dengan SPSS”.

Dwi Tri Jayanti. 2009. "Persepsi Mahasiswa Akuntansi Terhadap Faktor-

Faktor yang Mempengaruhi Pilihan Karir Menjadi Akuntan”. Skripsi. Universitas Negeri Yogyakarta

Erly Suandi. 2001. Panduan Uji Sertifikasi Konsultan Pajak. Jakarta:

Salemba Empat. 
Harry Susilo. 2008. “Minat Jadi Konsultan Pajak Rendah”. Diambil dari http://belajar psikologi.com/pengertian.minat/ Pada tanggal 30 Januari 2013

Haryanto. 2010. "Pengertian Minat Belajar". Diambil dari http://belajarpsikologi.com/pengertian-minat/ pada tanggal 30 Januari 2013"

Hetin Tridayanti. 2008. "Hubungan Antara Persepsi Mahasiswa Akuntansi Tentang Pendidikan Profesi Akuntansi Dengan Minat Untuk Mengikuti Pendidikan Profesi Akuntan”. Skripsi. Universitas Pamulang Marzuki. 2005. "Metodologi Riset (Panduan Penelitian Bidang Bisnis dan Sosial, Yogyakarta" : Penerbit Ekonisia Kampus Fakultas Ekonomi UII.

Melani Oktavia. 2005 . "Analisis Faktor-Faktor yang Memotivasi Pemilihan Karier Bagi Mahasiswa Akuntansi" (Studi Survey Pada Universitas Widyatama di Bandung), Skripsi, Universitas Widyatama Bandung Sugiyono. 2007. Statistika Untuk Penelitian. Bandung: Alfabeta.

Victor S.GTengker \& JennyMorasa, Dra., Msi., AK. 2007. ““"Pengaruh Motivasi Karir Terhadap Minat Mahasiswa Akuntansi Untuk Mengikuti Pendidikan Profesi Akuntansi (Ppak)"',. Jurnal. Universitas Sam Ratulangi. 